\title{
Analytical Method Development and Validation for Simultaneous Determination of Simvastatin and Mupirocin Using Reverse-Phase High-pressure Liquid Chromatographic Method
}

\author{
Ters Faz Yüksek Basınçlı Sıvı Kromatografik Yöntem Kullanılarak \\ Simvastatin ve Mupirosin Eşzamanlı Belirlenmesi için Analitik Yöntem \\ Geliştirme ve Validasyon
}

\author{
(D) Rupali KALE ${ }^{1 *}$, (D) Pratiksha SHETE², (D) Dattatray DOIFODE¹, (D) Sohan CHITLANGE² \\ 1Dr. D.Y. Patil Institute of Pharmaceutical Sciences and Research, Department of Pharmaceutics, Pimpri-Chinchwad, India \\ 2Dr. D.Y. Patil Institute of Pharmaceutical Sciences and Research, Department of Quality Assurance, Pimpri-Chinchwad, India
}

\begin{abstract}
Objectives: This study was aimed to develop and validate the use of reverse-phase high pressure liquid chromatographic method for the estimation of simvastatin (SIM) and mupirocin (MUP) simultaneously.

Materials and Methods: The chromatographic method developed is optimized for flow rate with the column, solvent, and buffer used and mobile phase ratio, molarity, and $\mathrm{pH}$. The validation of the optimized method and the forced degradation studies of both drugs (under acidic, alkaline, oxidation, heat, light, and neutral conditions) were conducted following the The International Council for Harmonisation of Technical Requirements for Pharmaceuticals for Human Use guidelines.

Results: Kromasil C18 column ( $250 \mathrm{~mm} \times 4.6 \mathrm{~mm}, 5 \mu \mathrm{m}$ ) with ultraviolet detection at $224 \mathrm{~nm}$ and acetonitrile/phosphate buffer (30 mM, $70: 30 \mathrm{v} / \mathrm{v}$, $\mathrm{pH}$ 3.5; adjustment done using orthophosphoric acid) as mobile phase at a flow rate of $1.1 \mathrm{~mL} / \mathrm{min}$ were observed to provide a good resolution for MUP and SIM at retention times of $2.32 \pm 0.008$ and $13.55 \pm 0.254$ min, respectively, with high accuracy (percent recovery was $99.69 \pm 0.82$ for MUP and $101.10 \pm 0.02$ for SIM) and linearity in the range of $5-30 \mu \mathrm{g} / \mathrm{mL}\left(r^{2}: 0.9969\right.$ for MUP and $r^{2}: 0.9959$ for SIM). The diagnostic limit and the lower limit of determination were $0.771 \pm 0.234$ and $2.338 \pm 0.246 \mu \mathrm{g} / \mathrm{mL}$ for MUP and $0.595 \pm 0.282$ and $1.803 \pm 0.334 \mu \mathrm{g} / \mathrm{mL}$ for SIM, respectively. The validated method was used to understand the degradation behavior of both drugs after the forced degradation studies.

Conclusion: The analytical method developed is determined to be specific, sensitive, precise, and accurate for the estimation of MUP and SIM simultaneously in the combined dosage form.
\end{abstract}

Key words: Simvastatin, mupirocin, validation, stability

öz

Amaç: Bu çalışmanın amacı, simvastatin (SIM) ve mupirosin (MUP) tahmininde eş zamanlı olarak ters fazlı yüksek performanslı sıvı kromatografik yöntemin kullanımını geliştirmek ve doğrulamaktır.

Gereç ve Yöntemler: Geliştirilen kromatografik yöntem kolon, çözücü ve tampon kullanılan akış hızı, mobil faz oranı, molarite ve pH için optimize edilmiştir. Optimize edilmiş yöntemin doğrulanması ve her iki uyuşturucunun (asidik, alkali, oksidatif, termal, ışık ve nötr koșullar için) zorunlu bozunma çalışmaları İnsan Kullanımına Yönelik Farmasötikler için Teknik Gereksinimlerin Uyumlaştırılması Uluslararası Konseyi yönergelerine göre gerçekleștirilmiştir.

Bulgular: Ultraviyole saptaması $224 \mathrm{~nm}$ 'deki C18 kolon (kromasil; $250 \mathrm{~mm} \times$ 4,6 mm, $5 \mu \mathrm{m}$ ) ve mobil fazda 1,1 mL/dk akış hızında ortofosforik asit

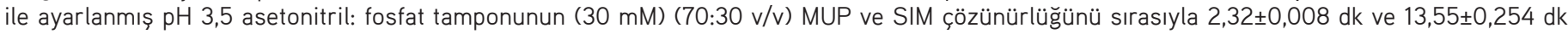




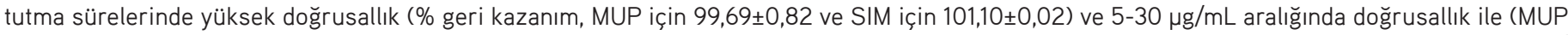

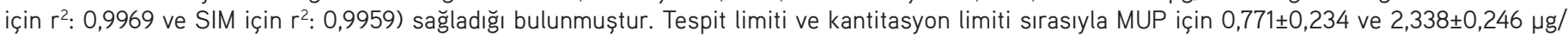

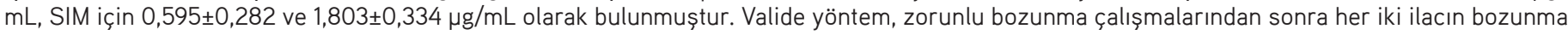
davranışını anlamak için kullanılmıştır.

Sonuç: Geliștirilen analitik yöntemin, kombine dozaj formunda MUP ve SIM'nin aynı anda tahmini için spesifik, hassas, kesin ve doğru olduğu belirlenmiştir.

Anahtar kelimeler: Simvastatin, mupirosin, validasyon, stabilite

\section{INTRODUCTION}

Mupirocin (MUP), chemically known as ( $\alpha E, 2 S, 3 R, 4 R, 5 S)$ 5-[(2S,3S,4S,5S)-2,3-epoxy-5-hydroxy-4-methylhexyl] tetrahydro-3,4-dihydroxy- $\beta$-methyl-2H-pyran-2-crotonic acid, ester with 9-hydroxynonanoic acid, calcium salt (2:1), dihydrate, is the most commonly used topical antibiotics., MUP is known to be active against Staphylococcus aureus and Staphylococcus epidermidis, which are aerobic Gram-positive cocci, and methicillin-resistant S. aureus, which is Gram-negative cocci. ${ }^{3}$ Topical ointment of $2 \%$ MUP is used as an antimicrobial agent for prophylaxis use in burns, operative wounds, and ulcers, as well as for the treatment of skin infections. ${ }^{4,5}$ Simvastatin (SIM), chemically known as (1S,3R,7S,8S,8aR)-8-[2-[(2R,4R)4-hydroxy-6-oxotetrahydro-2H-pyran-2-yllethyl]-3,7-dimethyl1,2,3,7,8,8a-hexahydronaphthalen-1-yl 2,2-dimethylbutanoate, is traditionally used in the treatment of various types of hypercholesterolemia, which decrease cholesterol by inhibiting the rate-limiting step in the synthesis of cholesterol. ${ }^{6}$ Other than this traditional application, the wound-healing activity of SIM has been recently explored as it improves vascular endothelial growth factor production, thereby stimulating angiogenesis, reducing oxidative stress, improving microvascular function, and enhancing endothelial function, which ultimately improves the wound-healing activity. ${ }^{7}$ These properties make SIM a drug of choice to be used in combination with antimicrobial agents. ${ }^{8}$

Various analytical methods for the analysis of individual drugs, as well as in combination with other drugs, have been reported, including ultraviolet (UV) spectrophotometry and highperformance liquid chromatography (HPLC). Abu-Nameh et al. ${ }^{9}$ proposed a simple HPLC method for the rapid analysis of SIM in commercial tablet formulation using a C18 Hypersil column and mobile phase composed of acetonitrile (ACN), phosphate buffer, and methanol with the ratio of 5:3:1 v/v/v and UV detection at $230 \mathrm{~nm}$. Bana et al. $^{10}$ reported the development of the UV spectroscopy and HPLC methods for the simultaneous estimation of halobetasol propionate and MUP. Effat and Masoud ${ }^{11}$ proposed the development and validation of the derivative spectrophotometric method for the analysis of SIM and ezetimibe by simultaneous estimation. Meanwhile, Dixit et al. ${ }^{12}$ proposed the development of the reverse-phase (RP)-HPLC method for the stability-indicating studies of the same drug combination Patel et al. ${ }^{13}$ developed the RP-HPLC method for the simultaneous determination of aspirin in combination with SIM using the analytical quality by design approach.

Literature search for prior articles on methods for the simultaneous analysis of SIM and MUP indicated no information reported for the simultaneous analysis of these two drugs by HPLC. The present study focused on the development of a simple, precise, and accurate RP-HPLC method for the simultaneous analysis of SIM and MUP in the combined dosage form. ${ }^{14}$

\section{MATERIALS AND METHODS}

\section{Materials}

Pure SIM and MUP were procured as gift samples from SAVA Healthcare Ltd. with their assay values. HPLC-grade solvents and chemicals purchased from Merck were used in this study.

\section{Instrument}

The instrument used in the proposed HPLC method was Agilent 1120 Compact LC System connected to a UV detector for analysis purposes. All of the data were acquired and processed using the EZChrom Elite Compact software. An analytical balance (Shimadzu) with $1 \mathrm{mg}$ sensitivity was used to weigh the samples.

\section{Development and optimization of the method for chromatographic conditions}

Method development and optimization for chromatographic conditions were conducted by varying the molarity (i.e., 25 and $30 \mathrm{mM}$ ), $\mathrm{pH}$ (i.e., 3.0, 3.5, and 4.0), and volume of ACN (i.e., 55, 65 , and $75 \mathrm{~mL}$ ) of the mobile phase and flow rate (1.0, 1.1, and $1.2 \mathrm{~mL} / \mathrm{min}$ ).

\section{Mobile phase}

The mobile phase was prepared by mixing ACN and phosphate buffer, and its $\mathrm{pH}$ was adjusted using orthophosphoric acid. The mobile phase was filtered through $0.45 \mu \mathrm{m}$ membrane filter paper after 15 min of sonication at room temperature before using it for analysis.

\section{Standard stock solution}

The standard stock solution of SIM and MUP was prepared individually. Accurately weighed $10 \mathrm{mg}$ of SIM was dissolved in $10 \mathrm{~mL}$ of the mobile phase in a volumetric flask $(1.000 \mu \mathrm{g} /$ $\mathrm{mL}$ ). A $1 \mathrm{~mL}$ aliquot from this solution was diluted with $10 \mathrm{~mL}$ of the mobile phase to obtain the final concentration of $100 \mu \mathrm{g} /$ $\mathrm{mL}$ SIM. The same procedure was repeated for MUP to obtain a solution of $100 \mu \mathrm{g} / \mathrm{mL}$ MUP.

\section{Sample solution}

The combined dosage form, which is in the form of a topical spray, is composed of $1.0 \% \mathrm{w} / \mathrm{v}$ each of SIM and MUP. ${ }^{14}$ Accurately measured quantity of $1.0 \mathrm{~mL}$ of the formulation consisting of SIM (10 mg) and MUP (10 mg) was transferred to a $100.0 \mathrm{~mL}$ volumetric flask, followed by the addition of 30 
$\mathrm{mL}$ mobile phase, ultrasonication of this solution for $20 \mathrm{~min}$ at room temperature, and volume make up to the mark with the mobile phase to obtain a concentration of $100 \mu \mathrm{g} / \mathrm{mL}$ for SIM and $100 \mu \mathrm{g} / \mathrm{mL}$ MUP.

\section{Optimization of chromatographic conditions}

Various preliminary trials were conducted during method development to understand the effect of certain parameters on their responses. For the mobile phase, the solvent was selected from $\mathrm{ACN}$ and methanol and the buffer was selected from ammonium acetate buffer and phosphate buffer based on the chromatographic responses received. The mobile phase was further optimized by varying the molarity of the buffer used and adjusting the $\mathrm{pH}$ from 3.0 to 4.5 using orthophosphoric acid.

\section{Chromatographic method for analysis}

After baseline stabilization (for approximately $30 \mathrm{~min}$ ), using the optimized chromatographic conditions, a standard solution of $20 \mu \mathrm{g} / \mathrm{mL}$ was successively injected into the system to record the chromatogram of the satisfactory reproducibility of the peak areas. This procedure was repeated for the sample solution, and the peak areas of the standard and sample were acquired to determine the concentrations of SIM and MUP in the sample. This analysis was repeated six times.

\section{Validation of the optimized method}

The International Harmonization Conference (ICH) Q2 (R1) guidelines ${ }^{15}$ were used to validate the developed analytical method. The validation parameters include system suitability test, specificity, accuracy, precision, linearity, robustness, limit of detection (LOD), limit of quantitation (LOQ), and stability.

\section{System suitability test}

The developed method was checked for system suitability using standard solutions $(100 \mu \mathrm{g} / \mathrm{mL})$ of SIM and MUP. Parameters of the resolution, tailing factor $(T)$, capacity factor, and theoretical plates $(N)$ were evaluated as results of system suitability with percent relative standard deviation (\% RSD) of six replicate injections.

\section{Specificity}

Method specificity was evaluated by comparing the chromatograms of the placebo and sample solutions prepared using the formulation consisting of SIM and MUP to check the interference of excipients. The placebo formulation has nearly the same composition as that of the sample solution, except that SIM and MUP were used to prepare the sample solution.

\section{Accuracy}

To determine the accuracy of the method, three different concentration levels of $80 \%, 100 \%$, and $120 \%$ for SIM and MUP were selected. These samples were analyzed in six replicates using the proposed method. The recovery studies for SIM were done by adding standard SIM at concentrations of 8,12 , and 24 $\mu \mathrm{g} / \mathrm{mL}$ to the known concentration of the sample $(10 \mu \mathrm{g} / \mathrm{mL})$ to be analyzed through the standard addition method. The content of the recovered SIM was analyzed. A similar procedure was repeated for the recovery studies of MUP. The percent recovery for both drugs was calculated separately.

\section{Precision}

The proposed method was evaluated for precision by checking its performance with intraday and interday variations of 8 , 12 , and $24 \mu \mathrm{g} / \mathrm{mL}$ of SIM and MUP. For intraday precision, six replicates of each concentration of the standard and sample solutions were injected consecutively on the same day. For interday precision, the same standard and sample solutions were injected on three different days. The \% RSD was calculated by determining the percent content of each sample injected.

\section{Linearity and range}

Six standard solutions of $5,10,15,20,25$, and $30 \mu \mathrm{g} / \mathrm{mL}$, with accuracy between $98 \%$ and $102 \%$ and precision of less than $2 \%$ RSD, were selected to assess linearity. These solutions were injected using the optimized method conditions, and the response acquired in terms of peak area was plotted against the respective concentrations. The linear relationship between peak area and concentration was evaluated by calculating the correlation coefficient, intercept, and slope.

\section{$\angle O D$ and $L O Q$}

To calculate the LOD and LOQ of SIM and MUP, the lower concentrations of the standard solution were injected. The LOD and $L O Q$ for both drugs were determined based on the $3.3 \mathrm{~s} / \mathrm{n}$ and $10 \mathrm{~s} / \mathrm{n}$ rule where $\mathrm{s} / \mathrm{n}$ is the signal-to-noise ratio.

\section{Robustness}

The robustness of the proposed method is evaluated to check its potential to resist small but intentional variations in the optimized parameters. For the robustness studies of the proposed chromatographic conditions, the mobile phase was varied as follows: $\mathrm{ACN} / \mathrm{phosphate}$ buffer ratio by $\pm 2 \%$, flow rate by $\pm 0.1 \mathrm{~mL} / \mathrm{min}$, wavelength by $\pm 1 \mathrm{~nm}, \mathrm{pH}$ by \pm 0.2 , and molarity of the buffer by $\pm 2 \mathrm{mM}$.

\section{Forced degradation studies}

Standard samples of SIM and MUP were exposed to different stress conditions, such as acidic, alkaline, oxidative, thermal, photostability, and neutral conditions, for the forced degradation studies. In the case of acidic and alkaline degradation, samples were treated with $0.1 \mathrm{M} \mathrm{HCl}$ and $0.1 \mathrm{M} \mathrm{NaOH}$ at $40^{\circ} \mathrm{C}$ for 24 h. Oxidative degradation was done using $3 \% \mathrm{v} / \mathrm{v}_{2} \mathrm{O}_{2}$ at $30^{\circ} \mathrm{C}$ for $24 \mathrm{~h}$. Thermal degradation was conducted by exposing the powder sample to $60^{\circ} \mathrm{C}$ for $24 \mathrm{~h}$ in an oven. Photostability was checked by exposing the sample to UV light by placing the sample in a UV chamber for $24 \mathrm{~h}$. For degradation under neutral conditions, the drugs were treated with water for $2 \mathrm{~h}$ at $80^{\circ} \mathrm{C}$. After the stipulated time, all of the samples were cooled to room temperature and analyzed using the optimized chromatographic conditions to assess the stability of the drugs.

\section{Stability}

The stability of the stock and sample solutions for the shortterm and long-term durations was checked by storing the solutions for $24 \mathrm{~h}$ and 3 days at room temperature, respectively. 
Each solution was observed individually for the appearance of solution after storage and analyzed in six replicates by HPLC using the optimized conditions. The retention time, peak shape, and assay of active substances were compared with freshly prepared solutions statistically.

\section{Statistical analysis}

All of the samples were analyzed in six replicates, and the RSD values were computed for all of the samples. Ethics committee approval or patient informed consent is not required for the proposed method.

\section{RESULTS AND DISCUSSION}

The RP-HPLC method was selected for the development of the analytical method for the estimation of SIM and MUP simultaneously because of its simplicity and suitability. The analytical method was developed and optimized to determine suitable chromatographic conditions for obtaining sharp and well-resolved peaks of SIM and MUP with minimal tailing.

\section{Column selection}

The C8 and C18 columns were checked for their performance in the proposed method. The drugs eluted earlier in the C18 column exhibited a satisfactory peak shape compared with the C8 column. Therefore, the Kromasil C18 column (250 $\mathrm{mm} \times 4.6 \mathrm{~mm}, 5 \mu \mathrm{m}$ ) was selected for the proposed method of simultaneous estimation of SIM and MUP.

\section{Mobile phase composition}

Mobile phase selection was done based on the polarity, pKa, and solubility of SIM and MUP, as well as the available literature data. Phosphate buffer ( $\mathrm{pH} 3.5$ ) or ammonium acetate buffer was selected as the aqueous phase and methanol or ACN was selected as the organic phase for mobile phase composition. Because ammonium acetate buffer did not show any peak for SIM and methanol was observed to increase column pressure and peak tailing, both were eliminated from the study and the combination of phosphate buffer and ACN was optimized further. Variation in the $\mathrm{ACN}$ /phosphate buffer ratio led to substantial changes in the chromatographic responses. A decrease in the $\mathrm{ACN} /$ phosphate buffer ratio resulted in increased retention time, as well as peak split; hence, the ACN/ phosphate buffer ratio of 70:30 (v/v) was selected for further optimization. Decreasing the molarity of the buffer from $30 \mathrm{mM}$ to $10 \mathrm{mM}$ resulted in a tailing factor of more than 2 . The mobile phase $\mathrm{pH}$ of less than 3.0 resulted in peak split, and the mobile phase $\mathrm{pH}$ of more than 4.0 resulted in increased retention time. The flow rate was optimized based on the peak properties (i.e., peak shape and symmetry) and retention time.

By conducting trials of different compositions of the mobile phase, the optimized mobile phase composition for the simultaneous estimation of SIM and MUP was ACN/30 mM pH 3.5 phosphate buffer $(70: 30, \mathrm{v} / \mathrm{v})$ with a flow rate of $1.1 \mathrm{~mL} / \mathrm{min}$ These optimized parameters were selected based on several factors, namely, theoretical plate (should be more than 2.000), retention time of both drugs (RSD should be less than 2 ), and tailing factor of both drugs (should be less than 2).

\section{Wavelength selection for detection}

The detection wavelength for the proposed method was determined by analyzing the isobasic points of SIM and MUP. Standard solutions of both drugs were prepared using stock solution ( $20 \mu \mathrm{g} / \mathrm{mL}$ each), scanning was done in the UV range of 400-200 nm using a UV-visible spectrophotometer (Shimadzu 1800), and overlaid spectra were recorded (Figure 1). The isobasic point of the overlaid spectra where the two substances absorb light of that specific wavelength $(224 \mathrm{~nm})$ to the same extent at the same analytical concentration was selected as the wavelength for detection during the analysis of MUP and SIM in the combined dosage form.

\section{Validation of the optimized method}

\section{System suitability test}

System suitability test is often used as the control strategy, which is an essential component of the HPLC method. The system suitability test is normally conducted to verify if the developed method has adequate resolution and reproducibility for the analysis to be conducted. For the proposed method, system suitability results viz. resolution (29.66 \pm 1.20$)$, capacity factor $(1.15 \pm 0.01$ for MUP and $11.31 \pm 0.01$ for SIM), retention time (RSD values of 0.01 for MUP and 0.25 for SIM), theoretical plate (5.162 \pm 0.02 for MUP and 8.518 \pm 0.07 for SIM), and tailing factor $(0.976 \pm 0.02$ for SIM and $1.16 \pm 0.02$ for MUP) were determined to be satisfactory.

\section{Specificity}

The results for the specificity of the proposed method are shown in Figure 2. The figure shows no interference in the retention time of SIM and MUP with a clear separation of peaks.

\section{Accuracy}

The accuracy of the proposed method was determined by conducting recovery experiments. The results for accuracy at different levels are listed in Table 1.

The percent recovery of SIM and MUP was determined to be close to $100 \%$, and the RSD values are less than $2 \%$, which

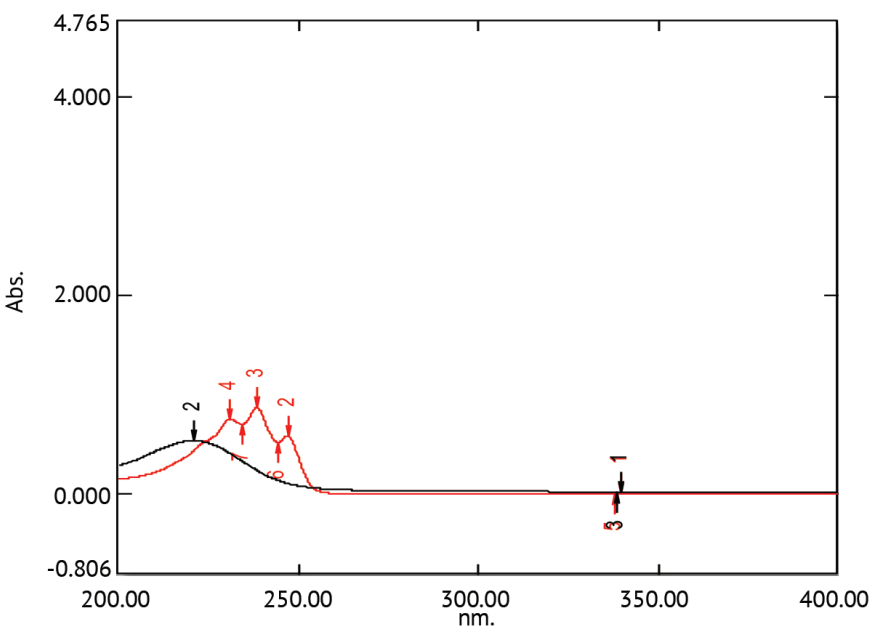

Figure 1. Overlaid spectra of MUP and SIM MUP: Mupirocin, SIM: Simvastatin 
fulfills the acceptance criteria for accuracy as indicated in the $\mathrm{ICH}$ guidelines. Hence, the method developed can be considered reliable for analytical application.

\section{Precision}

The results of intraday and interday precision using 8,12 , and $24 \mu \mathrm{g} / \mathrm{mL}$ concentrations of both SIM and MUP are listed in Table 2.

\section{Linearity and range}

The developed method was assessed for linearity at the concentration range of $5-30 \mu \mathrm{g} / \mathrm{mL}$. Calibration curve analysis indicated good correlation coefficients $\left(r^{2}: 0.9969\right.$ for MUP and $r^{2}$ : 0.9959 for SIM) for SIM and MUP in the given concentration range for both drugs. The regression equation for SIM was expressed as $y$ : $431.45 x+228.54$ and the regression equation for MUP was expressed as y: 449.25x-101.93, where y denotes the peak area and $x$ denotes the concentration.

$\angle O D$ and $L O Q$

The LOD and LOQ of the proposed method were determined to be $0.595 \pm 0.282$ and $1.803 \pm 0.334$ for SIM and $0.771 \pm 0.234$ and $2.338 \pm 0.246 \mu \mathrm{g} / \mathrm{mL}$ for MUP, respectively.
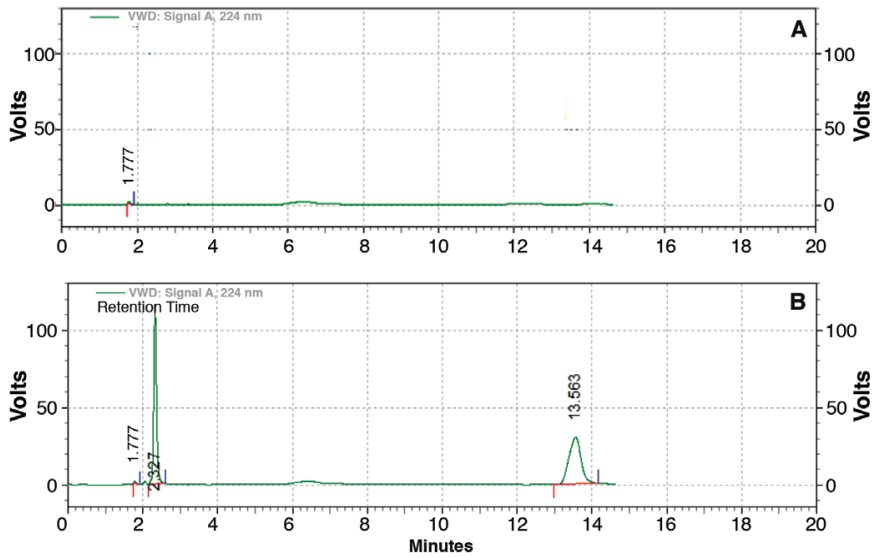

Figure 2. (A) Chromatogram of the placebo solution. (B) Chromatogram of the formulation showing simultaneous estimation of MUP at $2.33 \mathrm{~min}$ and SIM at 13.56 min of retention time

MUP: Mupirocin, SIM: Simvastatin

\section{Table 1. Percent recovery studies at three levels}

\begin{tabular}{llll}
$\begin{array}{lll}\text { Active } \\
\text { ingredients }\end{array}$ & $\begin{array}{l}\text { Analyte } \\
\text { concentration } \\
(\mu \mathrm{g} / \mathrm{mL})\end{array}$ & $\begin{array}{l}\text { Mean recovery } \\
(\%) \pm S E\end{array}$ & $\begin{array}{l}\text { RSD } \\
(\%)\end{array}$ \\
\hline SIM & \multirow{2}{*}{8.00} & $101.10 \pm 0.01$ & 0.02 \\
\cline { 3 - 4 } MUP & 12.00 & $101.08 \pm 0.16$ & 0.39 \\
\hline SIM & $99.67 \pm 0.02$ & 0.04 \\
\hline MUP & 24.00 & $100.29 \pm 0.01$ & 0.90 \\
\hline SIM & $99.41 \pm 0.01$ & 0.81
\end{tabular}

SE: Standard error, RSD: Relative standard deviation, MUP: Mupirocin, SIM: Simvastatin

\section{Robustness}

The results of the robustness of the developed method evaluated by changing the flow rate, mobile phase ratio, wavelength, $\mathrm{pH}$, and molarity of the buffer with the respective \% RSD values are listed in Table 3. The calculated assay (\%) values were in the acceptable range of $95.00 \%$ to $105.00 \%$ with \% RSD lower than 2, which indicated no significant effect on the results of

Table 2. Intraday and interday precision results of the proposed method

\begin{tabular}{lllll}
$\begin{array}{l}\text { Actual } \\
\text { concentration } \\
(\mu \mathrm{g} / \mathrm{mL})\end{array}$ & $\begin{array}{l}\text { Measured mean } \\
\text { concentration } \\
(\mu \mathrm{g} / \mathrm{mL}) \pm \mathrm{SE}\end{array}$ & \begin{tabular}{l} 
RSD \\
\cline { 2 - 5 }
\end{tabular} & $\begin{array}{l}\text { Measured mean } \\
\text { concentration } \\
(\mu \mathrm{g} / \mathrm{mL}) \pm \mathrm{SE}\end{array}$ & $\begin{array}{l}\text { RSD } \\
(\%)\end{array}$ \\
\cline { 2 - 5 } & $\mathrm{SIM}$ & & MUP
\end{tabular}

\begin{tabular}{lllll}
\hline Intraday & & & & \\
\hline 8.00 & $7.98 \pm 0.42$ & 1.02 & $8.12 \pm 0.47$ & 1.15 \\
\hline 12.00 & $11.87 \pm 0.62$ & 1.51 & $12.12 \pm 0.52$ & 1.27 \\
\hline 24.00 & $23.46 \pm 0.04$ & 0.19 & $23.27 \pm 0.04$ & 0.20 \\
\hline Interday & & & & \\
\hline 8.00 & $8.10 \pm 0.49$ & 1.21 & $7.61 \pm 0.11$ & 0.06 \\
\hline 12.00 & $11.97 \pm 0.40$ & 0.97 & $12.02 \pm 0.39$ & 0.95 \\
\hline 24.00 & $23.76 \pm 0.05$ & 0.28 & $23.48 \pm 0.03$ & 0.74 \\
\hline
\end{tabular}

\%RSD values lower than $2 \%$ indicate acceptable precision of the developed method. SE: Standard error, RSD: Relative standard deviation, MUP: Mupirocin, SIM: Simvastatin

Table 3. Robustness results of the proposed method

\begin{tabular}{|c|c|c|c|c|c|}
\hline \multirow[b]{2}{*}{ Factor } & \multirow[b]{2}{*}{ Variation } & \multicolumn{2}{|l|}{ SIM } & \multicolumn{2}{|l|}{ MUP } \\
\hline & & $\begin{array}{l}\text { Mean } \\
\text { amount } \\
(\%)\end{array}$ & $\begin{array}{l}\text { RSD } \\
(\%)\end{array}$ & $\begin{array}{l}\text { Mean } \\
\text { amount } \\
(\%)\end{array}$ & $\begin{array}{l}\text { RSD } \\
(\%)\end{array}$ \\
\hline \multirow{3}{*}{$\begin{array}{l}\text { Flow rate } \\
(\mathrm{mL} / \mathrm{min})\end{array}$} & 1.0 & 98.86 & 1.28 & 98.54 & 1.25 \\
\hline & 1.1 & 98.60 & 1.03 & 98.32 & 0.98 \\
\hline & 1.2 & 98.31 & 1.43 & 98.13 & 1.63 \\
\hline \multirow{3}{*}{$\begin{array}{l}\text { ACN/ } \\
\text { phosphate } \\
\text { buffer } \\
(70: 30, v / v)\end{array}$} & 68:32 & 98.38 & 1.54 & 98.12 & 1.39 \\
\hline & $70: 30$ & 98.73 & 0.98 & 99.10 & 1.34 \\
\hline & $72: 28$ & 98.67 & 1.27 & 98.78 & 1.28 \\
\hline \multirow{3}{*}{$\begin{array}{l}\text { Wavelength } \\
(\mathrm{nm})\end{array}$} & 223 & 97.59 & 1.50 & 97.30 & 1.23 \\
\hline & 224 & 98.60 & 0.97 & 99.21 & 1.32 \\
\hline & 225 & 98.01 & 1.38 & 98.45 & 1.30 \\
\hline \multirow{3}{*}{$\mathrm{pH}$} & 3.30 & 97.67 & 0.58 & 97.84 & 1.01 \\
\hline & 3.50 & 97.50 & 0.76 & 97.19 & 0.51 \\
\hline & 3.70 & 97.67 & 0.94 & 97.67 & 0.79 \\
\hline \multirow{3}{*}{$\begin{array}{l}\text { Molarity of } \\
\text { the buffer } \\
(\mathrm{mM})\end{array}$} & 28.00 & 97.39 & 0.82 & 97.67 & 0.78 \\
\hline & 30.00 & 97.70 & 0.78 & 97.70 & 1.18 \\
\hline & 32.00 & 97.51 & 0.77 & 97.38 & 1.13 \\
\hline
\end{tabular}

RSD: Relative standard deviation, MUP: Mupirocin, SIM: Simvastatin 
the analysis. These results showed that the developed method is robust to minor variations in system parameters.

\section{Forced degradation studies}

The analytical results after forced degradation of the samples are listed in Table 4, followed by the respective figures of the peaks after degradation. SIM was observed to degrade completely in alkaline conditions, followed by oxidative conditions $(10.64 \%)$, thermal conditions $(9.89 \%)$, and acidic conditions (4.85\%). Degradation in neutral conditions and photodegradation was observed to be less than $1 \%$. Dixit et al.12 reported similar results for the degradation behavior of SIM. In the case of MUP, maximum degradation was observed in acidic, oxidative, and neutral conditions (approximately $7 \%$ ), followed by thermal conditions (6.6\%). Degradation in alkaline conditions and photodegradation was observed to be less than $2 \%$. The capability of the proposed method to reveal the degradation peaks after forced degradation studies indicates the potential of the method as a stability-indicating analytical method. The degradation peaks did not show any interference in the retention times of the respective drugs, indicating the specificity of the analytical method developed (Figure 3-8).

\section{Stability}

The short-term stability (24 h) and long-term stability (3 days) of the stock and sample solutions did not show any precipitation or any other change in the appearance of the solution. The stock and sample solutions also did not show any significant difference in chromatographic responses, such as peak shape and retention time. The percent deviation between assay of freshly prepared and stored stock solutions was determined to be $1.12 \%$ for SIM and $0.91 \%$ for MUP in the case of short-term stability and $1.02 \%$ for SIM and $1.24 \%$ for MUP in the case of

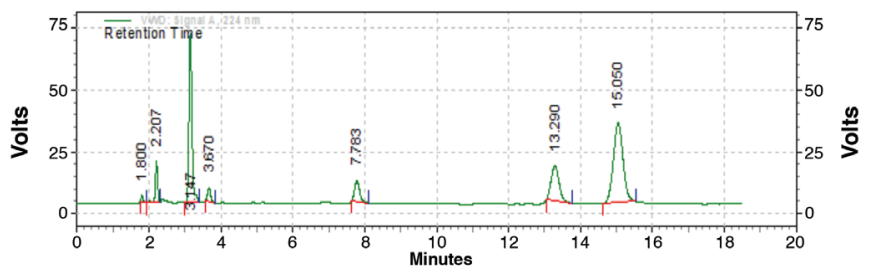

Figure 3. Degradation patterns of MUP and SIM under acidic conditions MUP: Mupirocin, SIM: Simvastatin long-term stability. By contrast, the percent deviation between assay of freshly prepared and stored sample solutions was determined to be $1.21 \%$ for SIM and $0.45 \%$ for MUP in the case of short-term stability and $0.07 \%$ for SIM and $1.45 \%$ for MUP

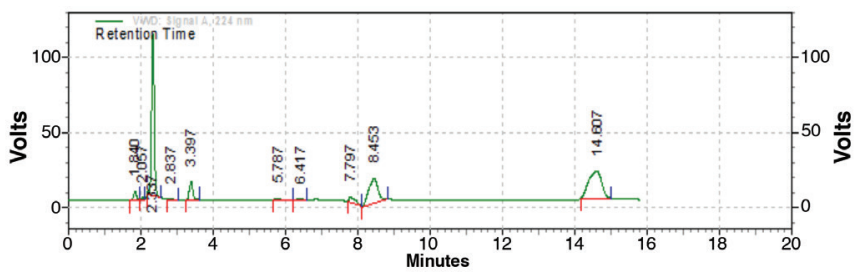

Figure 4. Degradation patterns of MUP and SIM under alkali conditions MUP: Mupirocin, SIM: Simvastatin

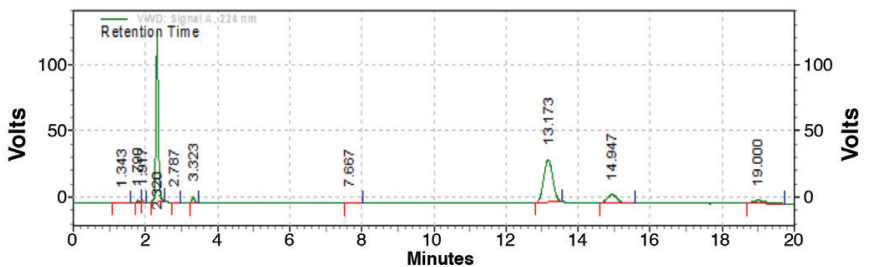

Figure 5. Degradation patterns of MUP and SIM under oxidative conditions MUP: Mupirocin, SIM: Simvastatin

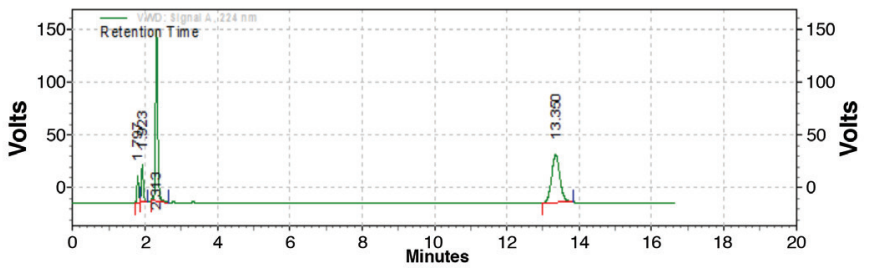

Figure 6. Degradation patterns of MUP and SIM under neutral conditions MUP: Mupirocin, SIM: Simvastatin

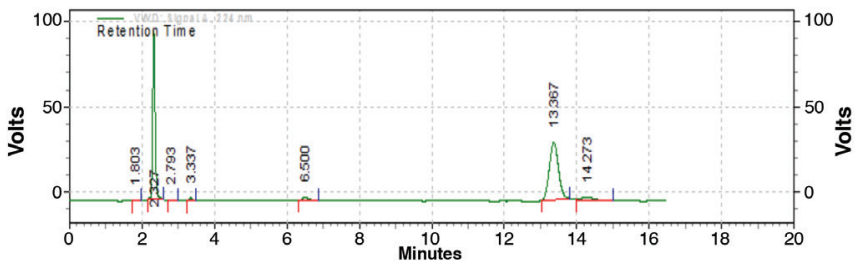

Figure 7. Degradation patterns of MUP and SIM under thermal conditions MUP: Mupirocin, SIM: Simvastatin

Table 4. Results of the forced degradation studies of the proposed method

\begin{tabular}{|c|c|c|c|c|c|c|c|c|}
\hline \multirow{2}{*}{ Stress conditions } & \multicolumn{2}{|c|}{ Amount of recovered SIM } & \multicolumn{2}{|c|}{ Amount of degraded SIM } & \multicolumn{2}{|c|}{ Amount of recovered MUP } & \multicolumn{2}{|c|}{ Amount of degraded MUP } \\
\hline & Mean (\%) & RSD (\%) & Mean (\%) & RSD (\%) & Mean $(\%)$ & RSD (\%) & Mean (\%) & RSD (\%) \\
\hline Acidic & 95.14 & 1.51 & 4.85 & 0.08 & 92.79 & 1.82 & 7.21 & 0.18 \\
\hline Alkali & - & - & 100.00 & 1.02 & 99.91 & 1.71 & 0.09 & 0.03 \\
\hline Oxidative & 89.32 & 1.21 & 10.64 & 0.15 & 92.65 & 0.91 & 7.35 & 0.30 \\
\hline Neutral & 99.14 & 1.32 & 0.85 & 0.01 & 92.65 & 1.35 & 7.35 & 0.26 \\
\hline Thermal & 90.81 & 1.77 & 9.89 & 0.07 & 93.40 & 1.43 & 6.60 & 0.07 \\
\hline Photodegradation & 99.01 & 1.24 & 0.99 & 0.02 & 98.57 & 1.59 & 1.43 & 0.09 \\
\hline
\end{tabular}

RSD: Relative standard deviation, MUP: Mupirocin, SIM: Simvastatin 


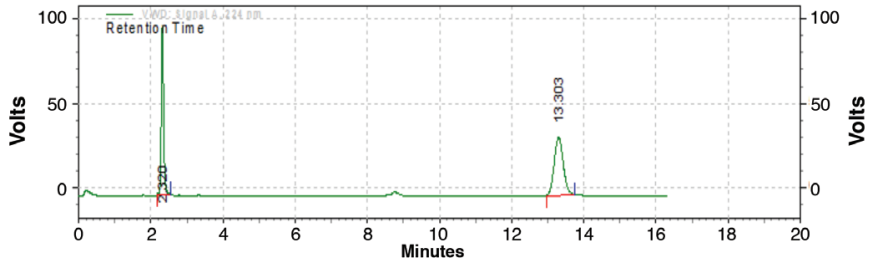

Figure 8. Degradation patterns of MUP and SIM after photodegradation MUP: Mupirocin, SIM: Simvastatin

in the case of long-term stability. These results indicate the stability of the stock and sample solutions for 3 days at room temperature.

\section{Analysis of the developed formulation}

The developed HPLC method was applied to the quantification of SIM and MUP in the developed formulation. The percent content of each drug was determined to be $97.80 \pm 0.31$ for MUP and $97.80 \pm 0.45$ for SIM. Hence, the developed method can be applied to the routine analysis of SIM and MUP in topical spray formulation, which has a combination of these two drugs.

\section{CONCLUSION}

A simple and convenient RP-HPLC method for the analysis of SIM and MUP in the combined dosage form was developed and validated. Kromasil C18 column ( $250 \mathrm{~mm} \times 4.6 \mathrm{~mm}, 5 \mu \mathrm{m})$ with UV detection at $224 \mathrm{~nm}$ and mobile phase composed of ACN/30 $\mathrm{mM} \mathrm{pH} 3.5$ phosphate buffer $(70: 30, \mathrm{v} / \mathrm{v})$ at a flow rate of 1.1 $\mathrm{mL} / \mathrm{min}$ were observed to provide a good resolution for MUP and SIM. The method was validated as per ICH guidelines, and the proposed method was determined to be specific, accurate, precise, and robust for the quantitation of SIM and MUP and can be applied to the routine analysis of the developed topical spray formulation, which has a combination of both drugs.

\section{ACKNOWLEDGMENTS}

The authors would like to thank SAVA Healthcare Ltd. for supplying the samples of MUP and SIM.

Conflict of interest: No conflict of interest was declared by the authors. The authors are solely responsible for the content and writing of this paper.

\section{REFERENCES}

1. Sujata S. Recent advances in topical wound care. Indian J Plast Surg. 2012;45:379-387.
2. Thornton SC, Taylor SC, Weinberg JM. Topical antimicrobial agents in dermatology. Clin Dermatol. 2003;21:70-77.

3. Dumville JC, Lipsky BA, Hoey C, Cruciani M, Fiscon M, Xia J. Topical antimicrobial agents for treating foot ulcers in people with diabetes. Cochrane Database Syst Rev. 2017;14;6.

4. Dai T, Huang YY, Sharma SK, Hashmi JT, Kurup DB, Hamblin MR. Topical antimicrobials for burn wound infections. Recent Pat Antiinfect Drug Discov. 2010;5:124-151.

5. Sarabahi S. Recent advances in topical wound care. Indian J Plast Surg. 2012;45:379-387.

6. Tripathi KD. Essentials of Medical Pharmacology, (6th ed). New Delhi: Jaypee Brothers Medical Publishers Ltd. 2008;636:776.

7. Bitto A, Minutoli L, Altavilla D, Polito F, Fiumara T, Marini H, Galeano M, Calò M, Lo Cascio P, Bonaiuto M, Migliorato A, Caputi AP, Squadrito F. Simvastatin enhances VEGF production and ameliorates impaired wound healing in experimental diabetes. Pharmacol Res. 2008;57:159169.

8. Akira E. A historical perspective on the discovery of statins. Proc Jpn Acad Ser B Phys Biol Sci. 2010;86:484-493.

9. Abu-Nameh ESM, Shawabkeh RA, Ali A. High-performance liquid chromatographic determination of simvastatin in medical drugs. Am J Anal Chem. 2006;61:63-66.

10. Bana A, Sathe MA, Rajput SJ. Analytical Method Development and Validation for Simultaneous Estimation of Halobetasol Propionate and Mupirocin in the ratio 1:40 by U.V. Spectroscopy And RP- HPLC Method. Int J Pharm Sci Res. 2019;10:1392-1401.

11. Effat S, Masoud A. Development and validation of a derivative spectrophotometric method for simultaneous determination of simvastatin and ezetimibe. J Chem. 2010;7:S197-S202.

12. Dixit RP, Barhate CR, Padhye SG, Viswanathan CL, Nagarsenker MS. Stability indicating RP-HPLC method for simultaneous determination of simvastatin and ezetimibe from tablet dosage form. Indian J Pharm Sci. 2010;72:204-210.

13. Patel KG, Patel AT, Shah PA, Gandhi TR. Multivariate optimization for simultaneous determination of aspirin and simvastatin by reverse phase liquid chromatographic method using $A Q b D$ approach. Bull Fac Pharm Cairo Univ. 2017;55:293-301.

14. Kale R, Doifode D, Shete P. Film forming, antimicrobial and growth promoting wound healing spray formulation. Int J Pharm Invest. 2020;10:320-325.

15. ICH Q2 (R1). Validation of analytical procedures: Text and Methodology. International conference on harmonization of technical requirements for the registration of pharmaceutical for human use. Geneva, Switzerland: 2005. Available from: https://www.ema.europa.eu/en/documents/ scientific-guideline/ich-q-2-r1-validation-analytical-procedures-textmethodology-step-5_en.pdf 